\title{
Serological Grouping of Virulent and Avirulent Strains of the Lobster Pathogen Aerococcus viridans
}

\author{
By JAMES F. STEENBERGEN, HUGH S. KIMBALL, \\ DAVID A. LOW, HARRIETTE C. SCHAPIRO \\ AND LEROY N. PHELPS \\ Department of Microbiology and Biology, San Diego State University, \\ San Diego, California 92182, U.S.A.
}

(Received 3 November 1976)

\begin{abstract}
SUMMARY
Virulent strains of Aerococcus viridans (formerly Gaffkya homari) are the aetiologic agents of gaffkemia, a septicaemic disease of the American lobster (Homarus americanus). The virulent and avirulent forms of this bacterium, previously thought to be taxonomically indistinguishable, have been differentiated by serological studies. Antisera were produced in rabbits using autoclaved bacteria as antigens. Reactions were measured by agglutination tests using microtitre techniques and an antigenic scheme was determined. Specific antisera were prepared by absorption and used to determine antigens of strains of $A$. viridans and other Gram-positive cocci. In general, only virulent strains of $A$. viridans have antigen $b$. Both virulent and avirulent strains possess other antigens also detected in strains of the genus Staphylococcus.
\end{abstract}

\section{INTRODUCTION}

From diseased American lobsters (Homarus americanus), Snieszko \& Taylor (1947) isolated a Gram-positive tetrad-forming coccus for which Hitchner \& Snieszko (1947) suggested the name Gaffkya homari. The pathogenicity of this bacterium for $H$. americanus was verified by Rabin (1965) and Stewart, Foley \& Ackman (1969). The genus name Gaffkya was rejected (Editorial Secretary, 1971) as a result of the work of Deibel \& Niven (1960), who recommended that the lobster pathogen be included in the genus Pediococcus.

Williams, Hirch \& Cowan (1953) recommended a new genus, Aerococcus, with the type species Aerococcus viridans, to accommodate strains of Gram-positive, tetrad-forming cocci isolated from air (Williams \& Hirch, 1950; Shaw, Stitt \& Cowan, 195I). Later, similar bacteria were isolated from other sources (Deibel \& Niven, 1960; Clausen, 1964; Mundt, Grahm \& McCarty, 1967; Colman, 1967; Kerbaugh \& Evans 1968). A number of studies have shown aerococci to resemble the lobster pathogen (Aaronson, 1956; Deibel \& Niven, 1960; Whittenbury, 1965; Sakaguchi \& Mori, 1969; Evans \& Schultes, 1969; Nakel, Ghuysen \& Kandler, 197I ; Schultes \& Evans, 197I). Kelly \& Evans (1974) recommended that the lobster pathogen be included in the genus Aerococcus as a variety of $A$. viridans. Puzniak, Chesbro \& Evans (197I) found that two strains of $A$. viridans were not pathogenic for the American lobster. Whether the lobster pathogen belongs to the genus Aerococcus or the genus Pediococcus, or to another genus, remains controversial. However, Bergey's Manual of Determinative Bacteriology (1974) incorporates the suggestions of Kelly \& Evans (1974) and both virulent and avirulent strains are included as $A$. viridans.

Little serological work has been done with $A$. viridans. Serological studies of Pediococcus strains (Gunther \& White, I96I ; Coster \& White, 1964) have shown that avirulent strains of 
Table I. Source and designation of bacterial strains

\begin{tabular}{|c|c|c|}
\hline Name (as received) & Strain designation & Sourcet \\
\hline Pediococcus homari* & $\begin{array}{l}\mathrm{Ph}-3 \\
\mathrm{Ph}-4,5,6,13,14,15,17,18,23,24,27,29,30,33 \text {, } \\
34,35,36,38,42,43 \\
\text { CSB-6, 7, II }\end{array}$ & $\begin{array}{l}\text { Nierengarten, G. M. } \\
\text { Kellogg, S. T. } \\
\text { F. Steenbergen }\end{array}$ \\
\hline$P$. pentosacens & 8081 & ATCC \\
\hline P. soyae & 13621 & ATCC \\
\hline Gaffkya homari* & $\begin{array}{l}\text { Ph-I, 7; Rabin; SABI6; StA8, I1, 13, 14, 15, 16, } \\
\text { I7, I8, 19, } 39 \\
10400\end{array}$ & $\begin{array}{l}\text { Stewart, J. E. } \\
\text { ATCC }\end{array}$ \\
\hline Aerococcus viridans* & $\begin{array}{l}\text { MK-3,32, 53, } 55,83,95,132,146,165,188,201 \text {, } \\
767,1486 \\
\text { FW-77, 80, } 82 \\
\text { WC-7, 10; LS-I } 7 ; 301 ; 302 ; 303 ; \mathrm{C}-7 \\
8251\end{array}$ & $\begin{array}{l}\text { Evans, J. B. } \\
\text { Evans, J. B. } \\
\text { Evans, J. B. } \\
\text { NCTC }\end{array}$ \\
\hline A. catalasicus & $c-6,9$ & Evans, J. B. \\
\hline Staphylococcus epidermidis & 14990 & ATCC \\
\hline Staph. aureus & $\begin{array}{l}\text { I } 2600 \\
\text { CN-I }\end{array}$ & $\begin{array}{l}\text { ATCC } \\
\text { F. Steenbergen }\end{array}$ \\
\hline Streptococcus lactis & 19435 & ATCC \\
\hline Strep.faecalis & 6057 & ATCC \\
\hline Strep. salivarius & 13419 & ATCC \\
\hline
\end{tabular}

A. viridans are distinct from the pediococci, but strains of the lobster pathogen were not included. The purpose of this study was to determine the serological relationships between virulent and avirulent forms of $A$. viridans.

\section{METHODS}

Bacteria. These are listed, with the names as received, in Table I. Stock cultures were maintained at room temperature on a solid medium and subcultured every Io days.

Media. Liquid medium was BBL Trypticase Soy Broth plus $0.3 \%$ (w/v) yeast extract (TSBY). Solid medium was TSBY plus $1.5 \%$ (w/v) agar. Media were sterilized by autoclaving at $121^{\circ} \mathrm{C}$ for $15 \mathrm{~min}$.

Antiserum production. Avirulent $A$. viridans strains MK-3 and MK-53, and virulent strains Ph-3, Ph-7, Ph-15, Ph-27, Ph-29, Ph-30, wC-7 and Stal 8 were used to prepare antisera. The bacteria were grown in $300 \mathrm{ml}$ TSBY for $20 \mathrm{~h}$, harvested, washed three times in saline, resuspended in $\mathrm{Io} \mathrm{ml}$ saline, and autoclaved for $\mathrm{I} \mathrm{h}$ at $\mathrm{I2I}{ }^{\circ} \mathrm{C}$. These preparations, adjusted to McFarland nephelometer standard number 10 , were used to raise antisera in rabbits by standard techniques. The antigen preparations were autoclaved because in this way serum titres were increased at least fourfold relative to those obtained with preparations that were not autoclaved. Absorbed antisera were prepared by the double absorption technique. The serum dilution ratio was $\mathrm{I}: 2$.

Agglutination tests. The antigen for agglutination tests was the same as the injected 
Table 2. Agglutination reactions of absorbed antisera

\begin{tabular}{|c|c|c|c|c|c|c|c|c|c|c|c|}
\hline Absorbed & Antibodies & & & & & Reactin & g strain & & & & \\
\hline & & MK-3 & Ph-I5 & WC-7 & Ph-7 & Ph-3 & StaI 8 & $\mathrm{Ph}-27$ & $\mathrm{Ph}-29$ & $\mathrm{Ph}-30$ & MK-53 \\
\hline $\begin{array}{l}\text { h-7(MK-3) } \\
\text { h-I } 5(\mathrm{Ph}-3) \\
\text { h-27(Ph-3) }\end{array}$ & & & & & & & & & & & \\
\hline $\left.\begin{array}{l}\text { Th-29(Ph-3) } \\
\text { h-3o(Ph-3) } \\
\text { tAI } 8(\mathrm{Ph}-3) \\
\mathrm{vC}-7(\mathrm{Ph}-3)\end{array}\right\}$ & $\mathbf{b}$ & - & + & + & + & - & + & + & + & + & $-\dagger$ \\
\hline $\left.\begin{array}{l}\mathbf{K K}-3(\mathrm{wC}-7) \\
\mathbf{K K}-3(\mathrm{Ph}-29)\end{array}\right\}$ & cd & + & - & - & - & + & - & - & - & - & - \\
\hline $\left.\begin{array}{l}\text { 'h-3(wC-7) } \\
\text { 'h-3(MK-53) }\end{array}\right\}$ & ce & + & - & - & - & + & - & - & - & - & - \\
\hline KK-3(wC-7, Ph-3) & d & + & - & - & - & - & - & - & - & - & - \\
\hline KK-53(Ph-7, Ph-3) & d & + & - & - & - & - & - & - & - & - & $-\ddagger$ \\
\hline h-3(wC-7, MK-3) & e & - & - & - & - & - & - & - & - & - & - \\
\hline (K-53(Ph-3)† & bd & $-\S$ & + & + & + & - & + & + & + & + & + \\
\hline KK-53(Ph-7, MK-3) & none & - & - & - & - & - & - & - & - & - & - \\
\hline
\end{tabular}

+ , Positive reaction; - , no detectable reaction.

* The absorbed serum is denoted as the original serum, with the strain used for absorption in parentheses. For example, wc-7 $(\mathrm{Ph}-3)$ is antiserum to strain wC-7 that has been absorbed with strain $\mathrm{Ph}-3$.

$\dagger \mathrm{MK}-53$ has a masked $\mathrm{b}$ antigen; see Discussion.

$\ddagger$ MK-53 has a partially masked d antigen; see Discussion.

$\S$ MK-3 reacts poorly with heterologous antisera. Reaction with this absorbed serum is too low to detect.

antigen, but was adjusted to McFarland nephelometer standard number 3. Tests were conducted using microtitre equipment (Cooke Engineering Co.) and clear U-bottom dilution plates (Linbro Chemical Co.). Plates were incubated for $2 \mathrm{~h}$ at $50^{\circ} \mathrm{C}$, and then overnight at $4{ }^{\circ} \mathrm{C}$, before examination under a dissecting microscope at $\times 10$ magnification. Each titration was repeated at least twice and a control containing equal volumes of saline and bacterial suspension was included with each titration.

All bacteria (Table I) were surveyed using specific absorbed antisera, diluted $I: 32$ in saline to minimize non-specific agglutination. Reactions were read as either positive or negative.

\section{RESULTS AND DISCUSSION}

Pre-immunization sera generally had titres of less than 4 , although a few had titres of 8 . A notable exception was that most of these sera had a titre of 32 to 64 against strain $\mathrm{Ph}-3$.

The Io Aerococcus strains reacted with all to unabsorbed antisera, although some titres were very low. These reactions could be due to a common antigen or to nonspecific crossreactions. We favour the former and propose a common antigen a.

When antisera to strains Ph-7, Ph-15, Ph-27, Ph-29, Ph-30, StaI 8 and wC-7 were absorbed with strains MK-3 or Ph-3, positive reactions still occurred with all strains tested except MK-3, MK-53 and Ph-3 (Table 2). This indicates the presence of a common antigen, $b$, in these strains. The following absorbed antisera gave negative results with all strains (the absorbed antiserum is denoted as the original serum, with the strain used for absorption in parentheses): Ph-15(Ph-7), Ph-7(Stal8), wC-7(Ph-7), Stai8(wC-7), Stai8(Ph-29) and $\mathrm{Ph}-29$ (wC-7). Apparently, antibodies a and $\mathrm{b}$ have been removed, and no other antibodies are detected. 
Table 3. Agglutination reactions of specific absorbed antisera

\begin{tabular}{|c|c|c|c|c|c|}
\hline Strain & Antigens & $\begin{array}{l}\text { Viru- } \\
\text { lence* }\end{array}$ & Strain & Antigens & $\begin{array}{l}\text { Viru- } \\
\text { lence* }\end{array}$ \\
\hline A. viridans & & & CSB-6 & c & + \\
\hline Ph-I & $b c \dagger d e$ & + & CSB-7 & d & + \\
\hline Ph- $3 \ddagger$ & c e & + & CSB-I I & c & + \\
\hline Ph-4 & b & + & MK-3ł & $c d$ & - \\
\hline Ph-5 & b & + & MK-32 & b & NT \\
\hline $\mathrm{Ph}-6$ & b & + & MK- $53 \ddagger$ & (b) $\S(d) \S$ & - \\
\hline $\mathrm{Ph}-7_{ \pm}^{+}$ & b & + & MK- 55 & d & \pm \\
\hline Ph-13 & b & + & MK-83 & & \pm \\
\hline Ph-14 & b & + & MK-95 & & \pm \\
\hline Ph-1 $5_{+}^{+}$ & b & + & MK-I 32 & & - \\
\hline Ph-I7 & b & + & MK-146 & & - \\
\hline Ph-1 8 & b & + & MK-I 65 & $c \dagger d e$ & \pm \\
\hline Ph-23 & b & + & MK-1 88 & $\mathrm{~cd}$ & - \\
\hline $\mathrm{Ph}-24$ & b & + & MK-20I & b & \pm \\
\hline Ph-27+ & b & + & MK-767 & b & \pm \\
\hline Ph-29 & b & + & MK-I 1486 & & \pm \\
\hline $\mathrm{Ph}-30_{+}^{+}$ & b & + & FW-77 & & \pm \\
\hline $\mathrm{Ph}-33$ & b & + & FW- 80 & $\mathrm{~cd}$ & - \\
\hline Ph-34 & b & + & FW-82 & & \pm \\
\hline Ph-35 & b & + & wC- $7 \ddagger$ & b & + \\
\hline Ph-36 & b & + & wC-Io & b & + \\
\hline Ph-38 & b & + & LS-17 & & NT \\
\hline Ph-42 & b d & + & 301 & & NT \\
\hline Ph-43 & $b$ & + & 302 & & NT \\
\hline SABI 6 & & + & 303 & & NT \\
\hline Rabin & b & + & 8251 & bcd & NT \\
\hline Sta8 & b d & + & $c-7$ & bcd & NT \\
\hline StaII & b & + & A. catalasicus $\mathrm{C}-6$ & $c d$ & NT \\
\hline Sta13 & b & + & A. catalasicus $\mathrm{C}-9$ & $\mathrm{~cd}$ & NT \\
\hline Stai4 & b & + & P. pentosacens $808 \mathrm{I}$ & & NT \\
\hline StaI5 & b & + & $P$. soyae 13621 & & NT \\
\hline Stai6 & b & + & Staph. epidermidis 14990 & c & NT \\
\hline StaI7 & $b d e$ & + & Staph. aureus 12600 & $c \nmid d e$ & NT \\
\hline Stal $8 \ddagger$ & b & + & Staph. aureus CN-I & $c \dagger d e$ & NT \\
\hline Stal9 & b & + & Strep. lactis 19435 & & NT \\
\hline Sta39 & bcde & + & Strep. faecalis 6057 & & NT \\
\hline 10400 & & NT & Strep. salivarius 13419 & & NT \\
\hline
\end{tabular}

* Virulence for $H$. americanus: + , virulent; \pm , intermediate virulence (Cherry, 1974); - , avirulent; NT, not tested.

+ Antigen $c$ in the presence of both $d$ and $e$.

\$ Strains to which antisera were prepared.

$\S$ Present as an immunogen, not an antigen.

The reactions of absorbed antisera MK-3(WC-7), MK-3(Ph-29), Ph-3(WC-7) and Ph-3(MK-53) indicate that strains MK-3 and $\mathrm{Ph}-3$ have an antigen in common, antigen c (Table 2). The reaction of absorbed antiserum $\mathrm{MK}-3$ (WC-7, $\mathrm{Ph}-3)$ indicates that $\mathrm{MK}-3$ has an antigen not shared by $\mathrm{Ph}-3$, antigen $\mathrm{d}$. The reaction of the absorbed serum MK-53(Ph-7, $\mathrm{Ph}-3)$ indicates that MK-53 shares a common antigen with MK-3, antigen $\mathrm{d}$ (Table 2). This is discussed later.

Table 3 shows the results of agglutination reactions of antigen-specific antisera with strains of $A$. viridans and representatives of other genera of Gram-positive cocci. Specific antisera could not be made for antigens a and c. Antisera specific for cd or ce were used to determine if, by inference, $c$ was present. Antigen $c$ could not be differentiated if antigens $c$ and $e$ were both present. 


\begin{tabular}{cccc} 
Table 4. Proposed antigenic scheme for Aerococcus viridans \\
Strain & Antigens present & Strain & Antigens present \\
MK-3 & a c d & Stal8 & a b \\
Ph-15 & a b & Ph-27 & a b \\
WC-7 & a b & Ph-29 & a b \\
Ph-7 & a b & Ph-30 & a b \\
Ph-3 & a c e & MK-53 & a (b)* (d)* \\
& \multicolumn{4}{c}{ *Masked antigens. }
\end{tabular}

In some cases, sera taken from rabbits before immunization gave agglutination titres of 32 to 64 . These titres indicate nonspecific reactions. Strain $\mathrm{Ph}-3$, which often gave such nonspecific reactions, possesses an antigen e (Table 3), which is shared in common with some strains of Staph. aureus. We suggest that the high nonspecific reactions are the result of prior exposure of the rabbits to Staph. aureus.

Some anomalous reactions were observed. The antisera prepared against strains MK-53, $\mathrm{Ph}-7, \mathrm{Ph}-15, \mathrm{Ph}-27$, and $\mathrm{Ph}-29$ gave higher titres with heterologous strains than with their homologous strain. Strain MK-53 was especially poor, giving many negative or prozone reactions and reactions of low titre; however, antisera to strain $\mathrm{MK}-53$ reacted well with most strains. In this study, a distinction is made between an immunogen and an antigen. Immunogenicity refers to the immunizing potential of a substance, whereas antigenicity refers to the reactivity of a substance with antibody. In order to react by agglutination with homologous antibody, an antigenic determinant must be on the outer surface of the bacterium. Certain surface antigens of strains MK-53 are apparently covered, or masked, by other surface structures. When this bacterium is injected into a rabbit, it is likely that partial digestion exposes the masked antigens. Thus, strain MK- 53 has good immunogenicity but poor antigenicity.

In rabbits, strain MK-53 induces the production of antibodies to antigens $b$ and $d$. In vitro strain MK-53 does not react with $b$ antisera, and so $b$ is a masked antigen. Strain MK- 53 reacts with $d$ antiserum from rabbits immunized with strain MK-53, but not with $d$ antiserum from rabbits immunized with strain MK-3; thus, antigen $d$ is partially masked. The chemical bases for these differences are under investigation. Similar masking phenomena with other strains, such as Ph-I5, could account for heterologous titres being greater than homologous titres and for other low or negative results.

The serological survey of some virulent and avirulent strains of $A$. viridans (Table 3) indicates that there is a good but not complete correlation between the presence of the $b$ antigen and virulence in the American lobster (Cherry, 1974). The b antigen is possessed by 4 I of the strains tested; of these, 35 are highly virulent for the American lobster, two are intermediate in virulence (Cherry, 1974), one (MK-53) is avirulent and three have not been tested.

These data support the conclusion of others (Aaronson, 1956; Whittenbury, 1965; Evans \& Schultes, 1969; Nakel et al., 1971 ; Schultes \& Evans, 197I ; Kelly \& Evans, 1974) that there is a very close taxonomic relationship between virulent and avirulent strains of $A$. viridans. The presence or absence of the $b$ or 'virulence' antigen would not, in itself, be sufficient to warrant dividing the organisms into two taxonomic groups.

Pediococcus pentosacens, $\boldsymbol{P}$. soyae and the three species of the genus Streptococcus did not react with typing sera (Table 3 ) indicating that they share no antigens with $A$. viridans. On the other hand, $A$. viridans apparently shares antigens with strains of the genus Staphylococcus. The two members of the genus Staphylococcus which were studied reacted with all typing antisera except for the $b$ antiserum. 
The proposed antigenic scheme for the Io $A$. viridans strains to which antisera were prepared is shown in Table 4.

We thank Dr J. B. Evans (Department of Microbiology, North Carolina State University, Raleigh, North Carolina, U.S.A.) and Dr J. E. Stewart (Fisheries Research Board of Canada, Halifax, Nova Scotia, Canada) for stock cultures of bacteria. This work is a result of research sponsored by NOAA Office of Sea Grant, Department of Commerce, under grant no. USDC 04-6-1 58-4402I.

\section{REFERENCES}

AARONSON, S. (1956). A biochemical-taxonomic study of a marine micrococcus Gaffkya homari and a terrestrial counterpart. Journal of General Microbiology 15, 478-484.

Bergey's Manual of DetrRminative Bacteriology, 8th edn (1974). Edited by R. E. Buchanan and N. E. Gibbons. Baltimore: Williams \& Wilkins.

CHeRry, J. F. (1974). Induced immunity in the American lobster, Homarus americanus, to Pediococcus homari. M.S. thesis, San Diego State University, U.S.A.

Clausen, O. G. (1964). The discovery, isolation and classification of various $\alpha$-haemolytic micrococci which resemble aerococci. Journal of General Microbiology 35, I-8.

Colman, G. (1967). Aeroccocus-like organisms isolated from human infections. Journal of Clinical Pathology 20, 294-297.

CosTER, E. \& WHirt, H. R. (1964). Further studies of the genus Pediococcus. Journal of General Microbiology $37,15-31$.

Deibel, R. H. \& Niven, C. F. (1960). Comparative study of Gaffkya homari, Aerococcus viridans, tetradforming cocci from meat curing brines, and the genus Pediococcus. Journal of Bacteriology 79, 175-180.

Editorial Secretary (1971). Rejection of the generic name Gaffkya Trevisan. International Journal of Systematic Bacteriology 21, 104-105.

Evans, J. B. \& Schultes, L. M. (1969). DNA base composition and physiological characteristics of the genus Aerococcus. International Journal of Systematic Bacteriology 19, 159-163.

GUNTHER, H. L. \& WHITE, H. R. (1961). Serological characters of the pediococci. Journal of General Microbiology 26, 199-205.

HITCHNER, E. R. \& SNIESzKo, S. F. (1947). A study of a microorganism causing a bacterial disease of lobsters. Journal of Bacteriology $54,48$.

Keluy, K. F. \& Evans, J. B. (1974). Deoxyribonucleic acid homology among strains of the lobster pathogen Gaffkya homari and Aerococcus viridans. Journal of General Microbiology 81, 257-260.

Krrbaugh, M. A. \& Evans, J. B. (1968). Aerococcus viridans in the hospital environment. Applied Microbiology 16, 519-523.

LANCRFIELD, R. C. (1933). A serological differentiation of human and other groups of hemolytic streptococci. Journal of Experimental Medicine 57, 571-595.

Mundt, J. O., GrahM, W. F. \& MCCARTY, I. E. (1967). Spherical lactic acid producing bacteria of southern-grown raw and processed vegetables. Applied Microbiology 15, 1303-1 308.

NAKel, M., GhuYSEN, J. M. \& KANDLER, O. (I971). Wall peptidoglycan in Aerococcus viridans strain 201 Evans and ATCC I 1563 and in Gaffkya homari strain ATCC 10400. Biochemistry 10, $2170-2175$.

Puzniak, C. J., Chesbro, W. R. \& Evans, J. B. (1971). Comparison of virulence of Gaffkya homari and Aerococcus viridans for Homarus americanus. Bacteriological Proceedings, 47.

RABIN, H. (1965). Studies of Gaffkemia, a bacterial disease of the American lobster, Homarus americanus (Milne-Edwards). Journal of Invertebrate Pathology 7, 391-397.

Sakaguch, K. \& Morr, H. (1969). Comparative study of Pediococcus halophilus, P. soyae, P. homari, P. urinae-equi and related species. Journal of General and Applied Microbiology 15, 159-167.

Schultes, L. M. \& Evans, J. B. (197I). Deoxyribonucleic acid homology of Aerococcus viridans. International Journal of Systematic Bacteriology 21, 207-209.

Shaw, C., StrTt, J. M. \& CowAN, S. T. (I951). Staphylococci and their classification. Journal of General Microbiology 5, 1010-1023.

SNIESZRo, S. F. \& TAYLOR, C. C. (1947). A bacterial disease of the lobster (Homarus americanus). Science 105, 500.

StewART, J. E., Foley, D. M. \& ACKman, R. G. (1969). Characteristics of Gaffkya homari, the causative agent of the lobster disease gaffkemia. Journal of the Fisheries Research Board of Canada 26, 1385-1389.

WhITTENBURY, R. (1965). A study of some pediococci and their relationship to Aerococcus viridans and the enterococci. Journal of General Microbiology 40, 97-ro6.

Wimirams, R. E. O. \& HIRCH, A. (1950). The detection of streptococci in air. Journal of Hygiene 48, 504-524.

Williams, R. E. O., HirCH, A. \& CoWAN, S. T. (1953). Aerococcus, a new bacterial genus. Journal of General Microbiology 8, 475-480. 